\title{
Threats to Rural Livelihoods in Nigeria: Implications for Social Order and Crisis Management
}

\author{
Iwundu Anthony Onyekwere, Kingsley Onyebuchim Nworgu \\ ${ }^{1}$ Department of Sociology, Imo State University, Owerri, Nigeria \\ ${ }^{2}$ Department of Mass Communication, Imo State University, Owerri, Nigeria \\ Email: iwu4toni@gmail.com, konworgu@gmail.com
}

How to cite this paper: Onyekwere, I. A., \& Nworgu, K. O. (2020). Threats to Rural Livelihoods in Nigeria: Implications for Social Order and Crisis Management. $A d$ vances in Applied Sociology, 10, 41-60. https://doi.org/10.4236/aasoci.2020.103004

Received: July 20, 2019

Accepted: March 13, 2020

Published: March 16, 2020

Copyright $\odot 2020$ by author(s) and Scientific Research Publishing Inc. This work is licensed under the Creative Commons Attribution International License (CC BY 4.0).

http://creativecommons.org/licenses/by/4.0/

\begin{abstract}
Rural livelihood arrangement in Nigeria is under severe threat and crisis. This is confirmed through this study that relied on the content analysis of 282 newspaper editions. For the sake of reliability, an evidence-based data spread sheet was obtained from 18 states, 486 communities using 24 reporters. The study was anchored on the DFID sustainable rural livelihood model. The objectives include: identifying the threat indicators and their sources; ascertaining the threat outcomes as well as the vulnerable groups and relating outcomes to threat factors; examining the extent of recovery implication during threats and associating threats with social order and security. The objectives were tested using descriptive statistics. Hypotheses were tested, using correlation technique, on the association between: 1) the presence of threat indicators and outcomes, 2) the presence of threat indicators and vulnerability of certain groups. The following findings were made: there is a relationship between the presence of threat factors and outcomes as well as the vulnerability of groups. Flooding of compounds and farms, herdsmen attacks, government impunity, gang violence constitute major threats to rural livelihood. The outcomes are insecurity, food crisis, loss of lives and property, hunger, loss of shelter, forced migration, diseases and suicide. Rural assets have been constrained; early recovery and resilience are poor. It is recommended that: Nigerians should take expert advice on seasonal stressors and government should stop arbitrary splitting of communities. Rural livelihood security programmes should target the women and farmers. Nomadic culture of cattle rearing should give way to ranches, Resilience and early recovery attitude should be encouraged among Nigerians.
\end{abstract}

\section{Keywords}

Rural Livelihood, Threat Factors, Threat Outcomes, Social Order, Crisis 
Management, Vulnerability and Resilience

\section{Introduction}

\subsection{Background to Rural Livelihood Threats}

Rural livelihood is about the means, strategies and activities for securing basic necessities in terms of food, water, shelter, medicine as well as the network of social combinations that enhance the lives of the rural dwellers. Livelihoods appear as substitute name for what goes on outside formal employment and the bureaucracies; in short, what people do in the informal economy. Chambers and Conway (1992) reported that: "A livelihood comprises the capabilities, assets (stores, resources, claims and access) and activities required for a means of living." Ellis (1999) defines livelihood as "the activities, the assets and the access that jointly determine the living gained by an individual or household while livelihood diversification is the process by which households construct a diverse port-folio of activities and social support capabilities for survival and in order to improve their standard of living". Akinwale (2011) affirms that "livelihood is a process by which people make a living through specific capabilities to include information sharing, social relationship management and identity maintenance".

For some years in Nigeria, writers have reported of rural livelihoods threats, constraints or displacement. Ellis (2003) forewarned on threats to rural livelihood thus:

"Poor households in low income countries construct their livelihood in a risky environment. For the rural, the risks are mainly related to climate shocks, personal shock of chronic illness, accidents and deaths. They build their livelihood in a context of pervasive uncertainty".

This study finds out the emergent trends in the threats to rural livelihood, highlights the tensions, crisis ambiguities and challenges associated with such threats. It addresses how age-long poor people's survival strategies have come under displacement and erosion, as well as how women, the ancient champions of rural livelihood are being constrained by threats and crisis. The overall implications of these on social disorder and insecurity in Nigeria were explained in the study.

\subsection{Problem Statement}

The severe threats that are confronting rural livelihood in Nigeria appear integral to social order, human security leading to crisis. With social disorder, nothing is spared-man, the environment, assets, food-supply and community life. The more pitiable situation is that women whose diverse portfolio livelihood activities used to sustain families and communities are being forced to withdraw from farms, places of trade and meetings due to crises. 
The study therefore examines the effects of these threats mainly severe flooding, Fulani herdsmen violence, communal clashes, government impunity and arbitrary acquisitions, gang violence on the social order and as constraints to rural livelihood activities. The study finds out the vulnerable groups and outcomes in the threat scenario. In view of these, the following objectives and related questions were examined:

1) What are the sources of threat to rural livelihood in Nigeria?

2) What are the threat indicators to rural livelihood in Nigeria?

3) Who are the most vulnerable groups to the threats to rural livelihood in Nigeria?

4) What are the outcomes due to threats to rural livelihood in Nigeria?

5) Are threat factors associated with noticeable outcomes?

6) Are threat factors associated with the emergence of most vulnerable groups?

7) What is the extent of recovery and resilience during threat episodes?

8) How are social order, human security and crisis management implicated during these threat episodes?

\subsection{Hypotheses}

Ho 1. There is no strong association between the presence of threat indicators and threat outcomes in Nigeria.

Ho 2. There is no strong association between threat indicators and vulnerability of certain groups in Nigeria.

\section{Literature Review}

\subsection{Rural Assets Which Are Prone to Threats}

The idea of rural assets is used interchangeably with rural resources and rural capital. Assets are supposed to assist in productive livelihood endeavours. They are incorporated in the people's strategies for mitigating poverty. Certain categories of assets have repeatedly occurred in the literature of poverty and development studies as well as in World Bank reports. They are physical asset, financial asset, human asset, social asset and natural asset (Moser \& Dani, 2008; Ellis, 2003; Narayan, 2000; Cord, 2002; DFID 2015 and Department of Agriculture, Environment and Development Economics, Ohio State University, 2015). The descriptive plan from the Department of Agriculture, Environment and Development Economics, Ohio State University (2015) appears sufficient to explain events in Nigeria. It is as follows:

Human Capital: Skills, knowledge, capacity for good health, to enable people pursue different livelihood strategies and achieve outcome.

Natural Capital: Natural resource stock such as trees, land, clean air, coastal resources which people rely upon for income and sense of well being.

Financial Capital: Savings and credit which come in form of cash, bank deposits, livestock and jewelry.

Social Capital: Formal and informal relationships which people employ to 
access information, achieve influence and power, claims and obligations from others.

Physical Capital: Public capital such as transport systems, water supply and sanitation, clean energy, good communication; Private physical capital such as shelter, bicycles, sewing machines, household goods and utensils.

The asset status or capital capacity of a group can come under threats, dislocations or pressure Human assets such as health may experience dislocation due to loss of persons, death or severe illness. In the same vein, educational facilities may be devastated. Environmental and natural assets may experience devastation, extreme conditions, seasonal fluctuations. Social capital needed for the coordination of other assets may not be forthcoming during episodes of violence and seasonal stress. Physical assets such as land may be constrained due to inaccessibility or poor quality. Savings and credit (financial assets) may be constrained due to local, state, national or even global policy shift.

\subsection{The Essence of Resilience and Early Recovery during Threats and Dislocations}

Resilience is about building the ability of the communities to absorb and recover from shocks that are due to environmental and socio-economic uncertainties and seasonal stresses. The OECD (2014) suggests the strengthening of three capacities:

Absorptive capacity; prepare for, mitigate or prevent negative impacts by using predetermined coping mechanisms like early harvest. Adaptive capacity; adjusting, modifying or changing its characteristics and actions to moderate future damage and take up opportunities such as diversification of livelihoods. Transformative capacity; creating fundamentally new system so that the shock will no longer have impact.

Early recovery is a post crises activity that catalyses sustainable re-development opportunities. For IASC Working Group (cited in UNDP, 2008) early recovery encompasses the restoration of basic services, livelihoods, shelter, governance, security and rule of law, environment and social dimensions, including the reintegration of displaced populations. UNDP (2008) adds that early recovery runs along humanitarian activities; both human and development actors work together. At the local level, communities participate in decision making, implementation, monitoring and evaluation of local programmes and that conditions are created for livelihoods to be rebuilt and damage to the social fabric repaired. Further, activities would revolve around reinforcing local administration, improve community security and restore cohesion; stabilize livelihoods and work out an integration of cross-cutting issues like risk reduction, conflict prevention, gender and environmental protection .The extent to which Nigeria and her agencies are into resilience and was revealed in this study.

\subsection{Social Order Implications of Threats}

Social order is about how and why societies cohere. It addresses the demise of 
community, disruption of social responsibility, loss of social control and general instability. To functionalist sociologists social order is achieved by integration of values and norms while for Marxists it is through coercion and economic compulsion by the dominant group (Scott \& Marshall, 2005). The other side of order is disorder, crisis, anomie and insecurity. Wrong (1994), while addressing "what unites and divides society" argues that order is matter of degree, co-exists with, influences and is influenced by individual deviance, group conflict, social change and cultural innovation and that the problem of order could not ignore human nature and the processes by which it is formed through contacts. Wrong (1994), marks anarchy, anomie, crime waves, insurrections, revolutions, civil wars, riots, mob violence and unconventional behaviour as instances of breakdown and collapse of order. In a more expatiated release, the UN Trust Fund for Human Security (1994) gives a table (see Table 1) of security types and their accompanying threats thus:

Human security relates to social order in its concern for stability as well as levels in key human development dimensions including freedom from want and fear (Gasper, 2005). In Nigeria fear, panic, flights, forced migration, hunger, displacements, loss of lives are common in media reports (Amaize, 2012; Amaize \& Omafuame, 2012; Bakare, 2015). There is also the eroding physical environment and dilapidation of infrastructure, seasonal stresses with rainy season exacting heavy toll on poor communities; crime and conflict, and rivalries among groups. (Okunmadewa, Aina, Ayoola, Mammon, Nwaeze, Odebiyi, Shehu, \& Zacha, 2002). It is noted by Dube and Phiri (2013) that effects of climate change on poor communities in sub-sahara African are becoming prominent and vulnerability is being compounded by high poverty levels.

\subsection{Democracy and Livelihood in Nigeria}

Democracy consists of five key elements: 1) universal adult suffrage, 2) recurring, free, competitive and fair elections, 3) more than one serious political party, 4) alternative sources of information, 5) some degree of political liberty beyond the electoral arena (Diamond \& Morlino, 2004). It has been observed that some depth of democracy is needed to explain poor livelihood outcomes in local

Table 1. The UN trust fund human security types.

\begin{tabular}{cc}
\hline Type of security & Examples of main threat \\
\hline Economic & Persistent poverty, unemployment. \\
Food & Human famine \\
Health & Deadly infectious diseases, unsafe food, lack of access to health facility \\
Environmental & Environmental degradation and resource \\
Personal & Physical violence, crime, terror acts \\
Community & Inter ethnic and identity based tension \\
Politics & Political repression and human rights abuses. \\
\hline
\end{tabular}


communities. Diamond (2005) supplies this in the role he assigned to civil liberties and to responsible and accountable governance. According to him civil liberties are in terms of their reduction of fear and torture, their engagement in informed networks, social movements, community based organizations to express the diversity of interests and mobilize for policy alternatives and social change while responsibility and accountability are in terms of government officials carrying out their responsibility honestly and transparently; private individuals and enterprises having formal protection to conduct legitimate commerce; existence of counter- corruption commissions; citizens having effective legal rights to obtain information on functions and decisions of government.

In a similar view Deihinger, Narayan and Sen (2009) agree that responsible government leads to improved governance and greater wellbeing of households as well as signs of improved law and order and less violence against women, hence communities with vibrant democracy tend to have better employment prospects and higher rate of movers than communities where democracy functions less well. In the same direction Dani and Moser (2008) 0pine that: "when given weak administrative outreach, poor people are often more vulnerable to insecurities arising out of state fragility, including crime, violence and absence of rule of law" Evidence of government failure, neglect and arbitrariness as they affect livelihood outcomes are buttressed in this study.

\section{Theoretical Framework}

The DFID sustainable rural livelihood model is the basis for this study. There are many presentations on DFID but this study uses that of Morce and McNamara (2013), while equally relying on explanations provided by Harvard Humanitarian Academy (2013). The model is an integrated approach on how certain factors interact during livelihood endeavours. It includes environmental sustainability as relevant to poverty. It also views the poor as a decision maker and not just a victim and as one with a set of priorities and resources (Harvard Humanitarian Academy, 2013). Factors in the model operate in a sequential relationship and with a feedback mechanism. They are: vulnerability context; livelihood assets; institutional and policy context (structures and processes); interventions that enhance livelihood strategies, livelihood outcome. The model is diagrammatical provided in Figure 1 below.

It is observed that assessment of various capital or assets gets support at individual, household and group levels (Figure 1). Such assessment takes place with their vulnerability context which constitutes certain happenings which the victims may not stop at the time they are taking place; the effects they may not cope with if unassisted. Interventions are put in place to assist the sustainability of livelihood strategies of the people. The interventions target the structures and policy processes, even the cultural ways of doing things.

\section{Methodology}

Content analysis, a systematic method of analyzing media message, was used in 


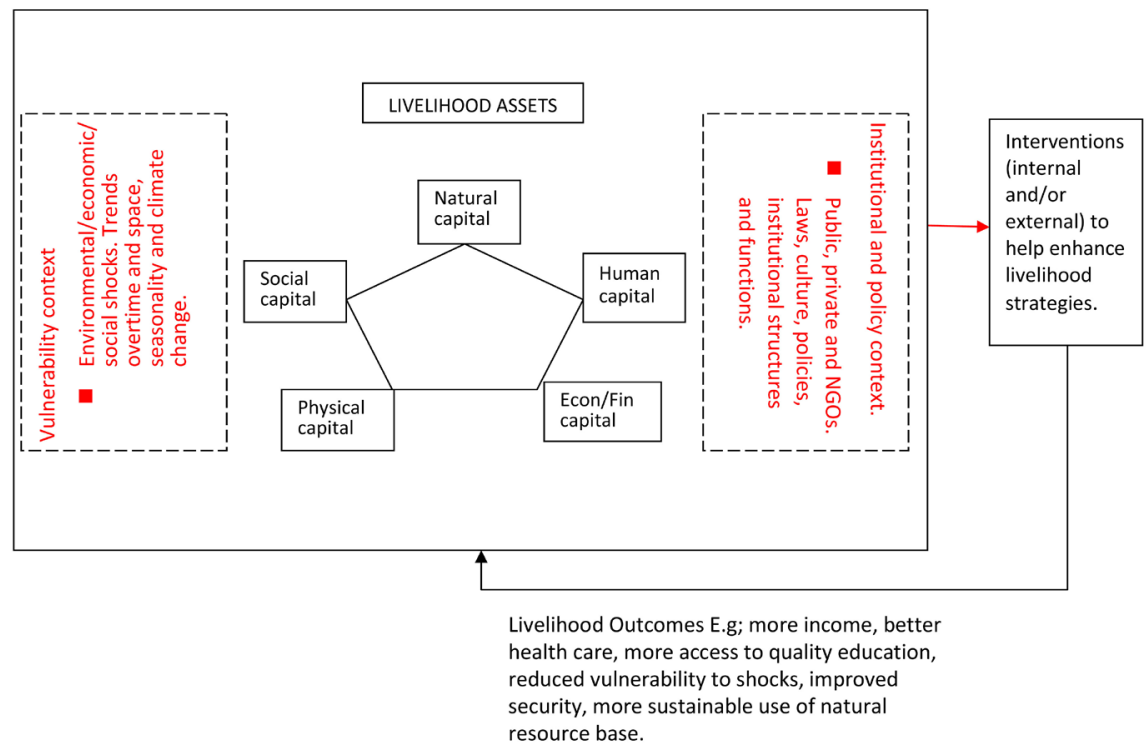

Figure 1. The DFID sustainable rural livelihood framework.

gathering data for this study. The study covered the period 2010 to 2015 and was restricted to newspaper reports. The following newspapers were purposely chosen: Vanguard, The Nation, Guardian, The Punch, Sun, This Day and The Leader. They were selected on the basis of public perception of their availability and credibility. They all displayed consistence in the reporting of environmental threats of 2012 and 2013 as well as government arbitrary conduct. The Leader is a weekly Faith based newspaper with wide circulation, highly patronized and reliable. Over the years it has been consistent in reporting of violence and herdsmen raids. A total of 282 newspapers were content analyzed. The unit of analysis is news stories while content categories of livelihood threats are mainly: flooding, herdsmen raids, government arbitrariness and gang violence. Most vulnerable groups, and outcome indicators were selected and their occurrence rates determined. The coverage was reports about 18 states of Nigeria. That means $50 \%$ of the states were sampled. Cluster sampling into six zones was done, with 3 states selected from each cluster area. This gave good geographical spread.

One limitation of this study is that it was based on data that was available in the newspapers. The news reporters and features writers may not have covered all threats and issues nor could they have observed all vulnerable groups. Reliability of the study was through pilot survey of livelihood threats conducted for the period under study using a sample of 35 newspaper editions. In addition a phi correlation cross tabulation technique for the determination of inter-judge reliability was employed and a P-value of 0.78 was realized. (Grant, Button, \& Snook, 2017). An evidence- based spreadsheet on threat to livelihood was derived (Appendix). This exercise guided the researchers in classifying livelihood threats and their outcomes as well as in categorizing the vulnerable groups. All these served the basis for the expanded data gathering that involved 282 newspapers. The terms used in study report were to a large extent generated from the 
field. Discussion of findings balanced the findings with reviewed literature and news reporters reviews and articles in the spreadsheet.

\section{Results}

Table 2 reveals that seven newspapers were sampled and that 282 editions were on the whole covered.

Total number of states covered in the media report $=18$. Table 3 reveals that government arbitrary conduct as a threat factor occurred in $83.3 \%$ of the states; Flooding in $77.8 \%$; Herdsmen raids in $72.2 \%$ while gang violence occurred in $27.8 \%$ of the states. The occurrences (incidents) of each threat factor are: government arbitrary conduct appeared 96 times, giving an incident rate of 347.8; flooding appeared 82 times, an incident rate of 297.1; violence and gang activities appeared 50 times, an incident rate of 181.1; herdsmen raids occurred 48 times, an incident rate of 173.9 (see Figure 2).

Table 4 reveals the following threat outcome occurrences and rates by their categories: insecurity, violence and kidnapping, 72 occurrences, giving an occurrence rate of 182.2; loss of lives and property, 50, occurrence rate of 126.5, hunger and cut off from food supply, 58, an occurrence rate of 146.8; displacement

Table 2. Newspapers sampled.

\begin{tabular}{cc}
\hline Newspaper & Number of editions \\
\hline Vanguard & 43 \\
Guardian & 43 \\
The Nation & 43 \\
Sun & 43 \\
This Day & 43 \\
Punch & 43 \\
The Leader & 24 \\
& $\mathbf{2 8 2}$
\end{tabular}

Table 3. Livelihood threat indicators.

\begin{tabular}{cccccc}
\hline $\begin{array}{c}\text { Flooding/submerging } \\
\text { of compounds } \\
\text { and farms. }\end{array}$ & $\begin{array}{c}\text { Herdsmen } \\
\text { raids }\end{array}$ & $\begin{array}{c}\text { Government } \\
\text { arbitrariness } \\
\text { in splitting of } \\
\text { communities }\end{array}$ & $\begin{array}{c}\text { Violence } \\
\text { and gang } \\
\text { activities }\end{array}$ & Total & $\begin{array}{c}\text { Flooding/submerging } \\
\text { of compounds } \\
\text { and farms. }\end{array}$ \\
\hline $\begin{array}{c}\text { Number of } \\
\text { states reported }\end{array}$ & $14 / 18$ & $13 / 18$ & $15 / 18$ & $5 / 18$ & \\
$\begin{array}{c}\% \text { states reported of } \\
\text { a threat category }\end{array}$ & $77.8 \%$ & $72.2 \%$ & $83.3 \%$ & $27.8 \%$ & \\
$\begin{array}{c}\text { Number of } \\
\text { incidents reported }\end{array}$ & 82 & 48 & 96 & 50 & 276 \\
$\begin{array}{c}\text { Incidents } \\
\text { (occurrences) rates }\end{array}$ & 297.1 & 173.9 & 347.8 & 181.1 & \\
\hline
\end{tabular}


Table 4. Livelihood threat indicator outcome.

\begin{tabular}{|c|c|c|c|c|c|c|c|c|c|c|}
\hline & $\begin{array}{l}\text { Insecurity, } \\
\text { violence and } \\
\text { kidnapping }\end{array}$ & $\begin{array}{c}\text { Loss of } \\
\text { lives/property }\end{array}$ & $\begin{array}{l}\text { Hunger/cut } \\
\text { off from } \\
\text { food supply }\end{array}$ & $\begin{array}{c}\text { Displacement } \\
\text { and loss } \\
\text { of shelter }\end{array}$ & $\begin{array}{l}\text { Fear } \\
\text { and } \\
\text { panic }\end{array}$ & $\begin{array}{l}\text { Flight/forced } \\
\text { migration }\end{array}$ & Diseases & Suicide & $\begin{array}{l}\text { Being } \\
\text { trapped }\end{array}$ & Total \\
\hline $\begin{array}{l}\text { Occurrences } \\
\text { in the report }\end{array}$ & 72 & 50 & 58 & 54 & 70 & 40 & 23 & 8 & 20 & 395 \\
\hline$\%$ Occurrence & 18.2 & 12.7 & 14.7 & 13.7 & 17.7 & 10.1 & 5.8 & 2.0 & 5.1 & $100 \%$ \\
\hline Occurrence rate & 182.2 & 126.5 & 146.8 & 136.7 & 177.2 & 101.2 & 58.2 & 20.2 & 50.6 & \\
\hline
\end{tabular}

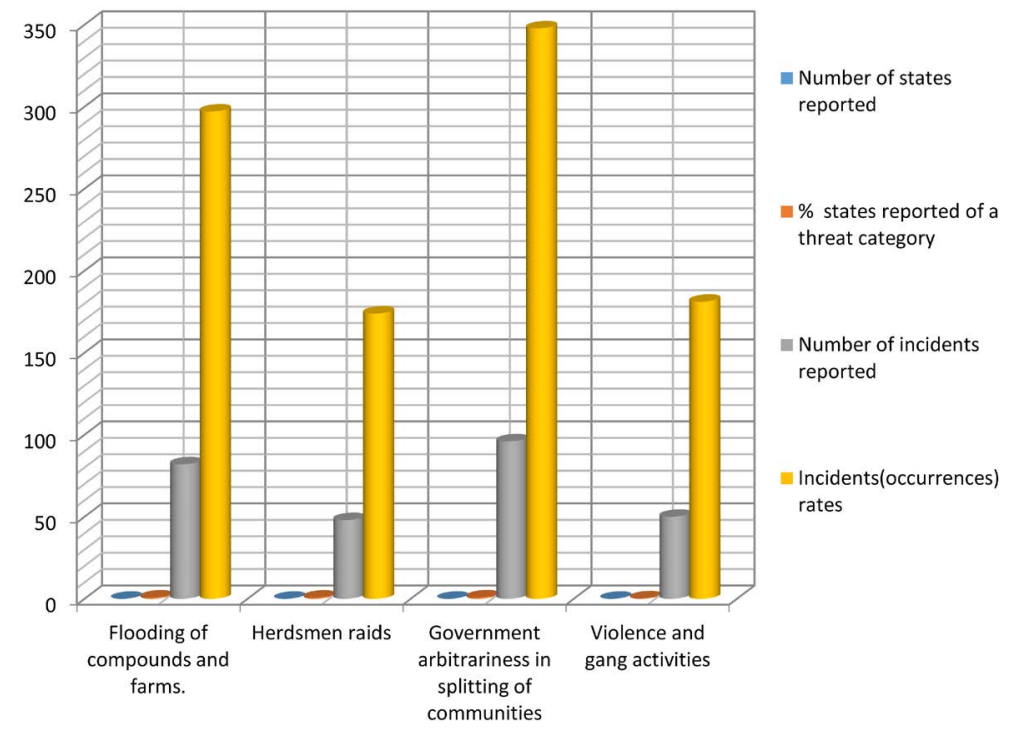

Figure 2. Livelihood threats indicators graphical presentation.

and loss of shelter, 54, an occurrence rate of 136.7; fear and panic, 70, an occurrence rate of 117.2; flight and forced migration, 40, an occurrence rate of 101.2; diseases, 23, an occurrence rate of 58.2; suicide, 8 , an occurrence rate of 20.2; being trapped, 20, giving an occurrence rate of 50.6 (see Figure 3 ).

Table 5 reveals that farmers, as a vulnerable group, was reported 75 times, vulnerability rate 238.1; women, 58 times, vulnerability rate 184.1; children, 60 times, vulnerability 190.4; youth/community leaders, 45 times, vulnerability 142.8; fishermen, 18 , vulnerability 57.1 ; aged/disabled persons, 20 , vulnerability 63.4; widows, 15, vulnerability 47.6; students, 24 times, vulnerability 76.1(see Figure 4).

Table 6 reveals the levels of intervention, resilience and post crisis recovery efforts. Intervention by NEMA, SEMA and LEMA (National Emergency Management Agency, State Emergency Management Agency, Local Emergency Management Agency respectively) was well reported. Intervention by civil defense and related agencies was fairly reported. Agencies restoring basic services were poorly reported. There was no report of any deliberate restoration of social connections after the shocks, non on agencies coming back to engage communities for evaluation and non on the availability of civil liberty groups (see Table 6 and Figure 5). 


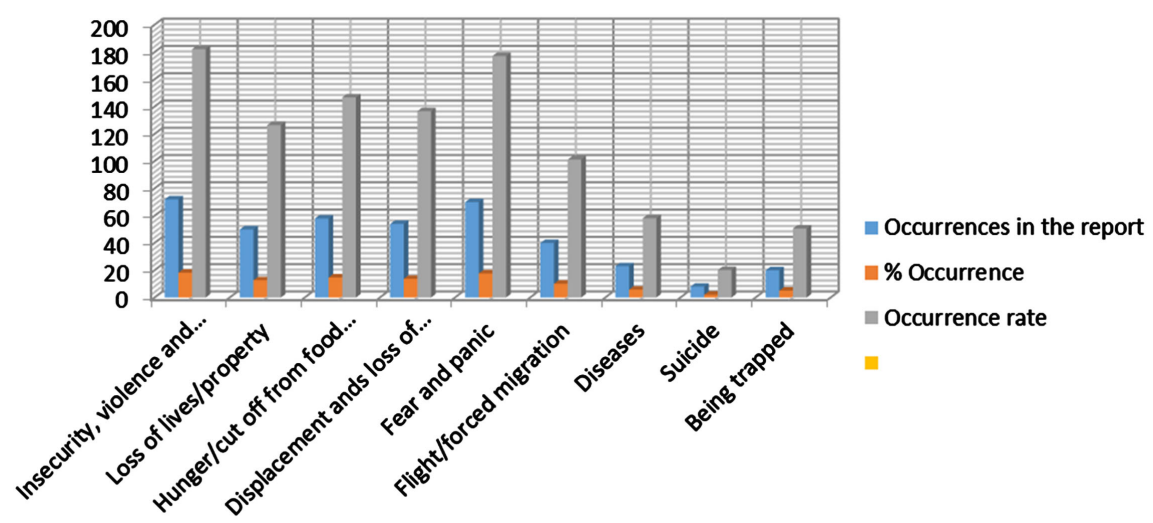

Figure 3. Livelihood threat indicators outcome graphical presentation.

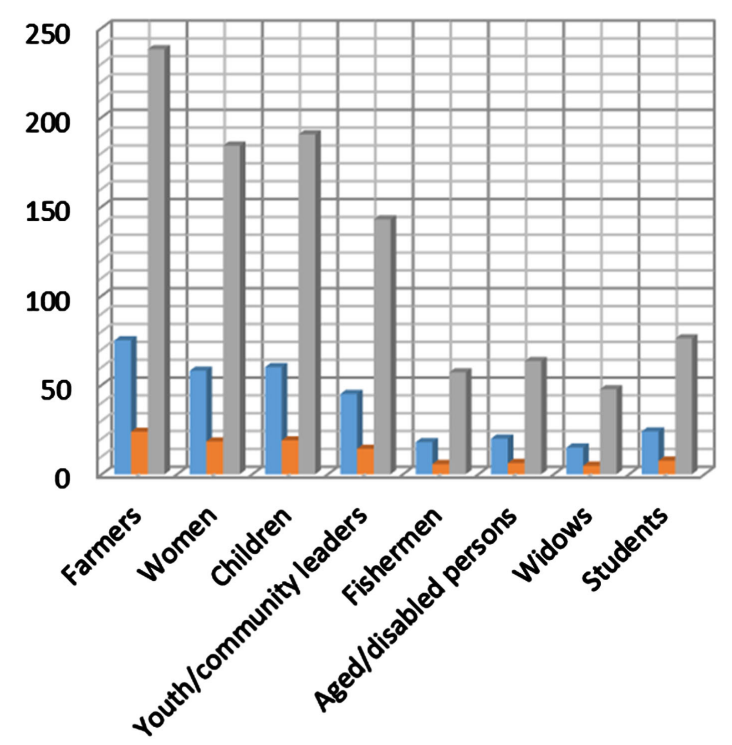
Number of occurrences in the report

nulnerability ratio

Vulnerability rate

Figure 4. Most vulnerable groups in livelihood threats - graphical presentation.

Table 5. Most vulnerable groups in livelihood threats.

\begin{tabular}{cccc}
\hline Group Type & $\begin{array}{c}\text { Number of } \\
\text { occurrences } \\
\text { in the report }\end{array}$ & $\begin{array}{c}\text { Vulnerability } \\
\text { ratio }\end{array}$ & $\begin{array}{c}\text { Vulnerability } \\
\text { rate }\end{array}$ \\
\hline Farmers & 75 & 23.8 & 238.1 \\
Women & 58 & 18.4 & 184.1 \\
Children & 60 & 19.0 & 190.4 \\
Youth/community leaders & 45 & 14.3 & 142.8 \\
Fishermen & 18 & 5.7 & 57.1 \\
Aged/disabled persons & 20 & 6.3 & 63.4 \\
Widows & 15 & 4.8 & 47.6 \\
Students & 24 & 7.6 & 76.1 \\
Total & 315 & 100 & \\
\hline
\end{tabular}




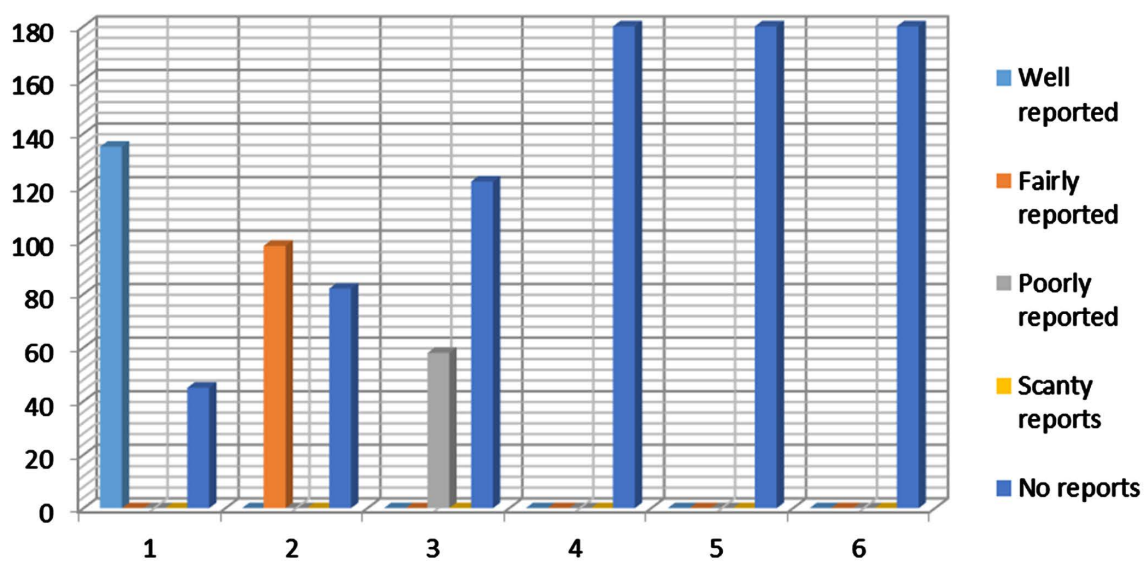

Figure 5. Reports about interventions, resilience and post crisis recovery efforts.

Table 6. Reports about interventions, resilience and post crisis recovery efforts.

\begin{tabular}{|c|c|c|c|c|c|c|}
\hline \multirow[b]{2}{*}{ Nature of report } & \multicolumn{6}{|c|}{ Levels of report } \\
\hline & $\begin{array}{c}\text { Well } \\
\text { reported }\end{array}$ & $\begin{array}{l}\text { Fairly } \\
\text { reported }\end{array}$ & $\begin{array}{l}\text { Poorly } \\
\text { reported }\end{array}$ & $\begin{array}{l}\text { Scanty } \\
\text { reports }\end{array}$ & $\begin{array}{l}\text { No } \\
\text { reports }\end{array}$ & Total \\
\hline $\begin{array}{l}\text { Intervention by NEMA, } \\
\text { SEMA, LEMA }\end{array}$ & $\begin{array}{l}135 \text { reports } \\
(75 \%)\end{array}$ & 0 & 0 & 0 & 45 & 180 \\
\hline $\begin{array}{l}\text { Intervention by civil } \\
\text { defence and } \\
\text { related agencies }\end{array}$ & - & $\begin{array}{c}98 \text { reports } \\
(54 \%)\end{array}$ & - & - & - & 180 \\
\hline $\begin{array}{l}\text { Agencies restoring } \\
\text { basic services }\end{array}$ & - & - & $\begin{array}{c}58 \text { reports } \\
(32 \%)\end{array}$ & - & - & 180 \\
\hline $\begin{array}{c}\text { Deliberate restoration } \\
\text { of social connections } \\
\text { after shocks }\end{array}$ & - & - & - & - & 180 & 180 \\
\hline $\begin{array}{l}\text { Agencies coming back } \\
\text { to engage communities } \\
\text { for evaluation }\end{array}$ & - & - & - & - & 180 & 180 \\
\hline $\begin{array}{l}\text { Availability of civil } \\
\text { liberty groups }\end{array}$ & - & - & - & - & 180 & 180 \\
\hline
\end{tabular}

\section{Tests of Hypotheses}

\subsection{The Association between the Presence of Threat Indicators and Threat Outcomes}

Threat indicator rates:

1) Flooding of compounds and homes (297.1)

2) Herdsmen raids (173.9)

3) Government arbitrariness and splitting of communities (347.8)

4) Gang activities (181.1)

Outcome indicator rates:

5) Insecurity, violence and kidnapping (182.2)

6) Loss of lives and property (126.5)

7) Hunger and cut off of food supply (146.8) 
8) Displacement and loss of shelter (136.7)

Results based on spearman rho correlation reveals an r-value 0.8; A t-test value of 22.31; df $\mathrm{n}-2=280$; table value ( $\rho=0.05,1.64$ on t-table of distribution) The Null hypothesis is rejected, an indication that the presence of certain threat variables were responsible for the emerged outcomes (see Appendix).

\subsection{The Association between the Presence of Threat Indicators and the Vulnerability Outcomes}

Threat indicator rates:

1) Flooding of compounds and homes (297.1)

2) Herdsmen raids (173.9)

3) Government arbitrariness and splitting of communities (347.8)

4) Gang activities (181.1)

Vulnerability groups:

5) Farmers (238.1); F. Women (184.1); G. Children (190.4); H. Youth and community leaders (142.8).

Results based on Spearman rank order correlation reveals an r-value 0.6; A t-test value 15.68 , df $n-2,280 ; \rho=0.05,1.64$ on $t$-table of values. The Null hypothesis is rejected; an indication that the presence of threat variables affected the categories of vulnerable groups in the report. The correlation coefficient of 0.6 also shows a high positive association between threat indicators and vulnerability of certain groups.

\section{Discussion of Findings}

Major threats to livelihood in the period surveyed are flooding of compounds and farms, herdsmen attacks, government arbitrary conducts, violence and gang activities Flooding, more especially has repeatedly occurred as the worst threat factor followed by government arbitrariness and impunity, then herdsmen and gang activities. Flooding started in 2010 and came to a peak in September, through October and November 2012. Reports by Udo, Ojinaka, Baywood and Gift (2015) show that in the 2012 disaster, about fourteen states that border the Niger-Benue river were severely affected, the worst being Korgi, Edo, Anambra and Delta states. The flood submerged houses severed transportation routes while an estimate of 1.3 million people were displaced, 431 lives were lost and about 1525 square kilometers of farm land were destroyed. In the worst stages of 2012, it was described by the media as "the rage of nature" (Ajani, 2012). The danger in the herdsmen threat has been captured thus:

It is indeed one of the curious tragedies of modern Nigeria that we have come to accept the category "nomadic" as a permanent description of a vital segment of our populace. We have gone ahead to create schools, map out grazing trails and sundry other things to enshrine this unfortunate doctrine. A consequence has been the ever frequent bloody clashes between nomads and settled landowners and farmers in nearly every part of the country, and now the involvement of nomads in aspects of our emerging national crime culture, kidnapping for ran- 
som (Ishaka, 2015).

It is also reported that "farmland were destroyed, while women, young girls and children are raped... herdsmen stage highway robbery attacks" (Itua, 2013). A popular politician, one time Secretary to Federal Government, Olu Falae, was kidnapped by herdsmen and his farm destroyed by cattle (Sowale, 2015). Clearly, communities are being sacked and women are withdrawing.

Threat types in Nigeria are in tandem with the human security threat types presented by UN Trust Fund for Human Security (2009) which covered environmental degradation and resource depletion; lack of access to facilities, violence, crime and terror acts; identity based tensions, human rights abuses.

This study revealed the extent to which government impunity has become a serious threat factor to the rural poor. This threat type has been manifesting in the creation of new communities, splitting of old communities, imposition of heads, all without consultation with the people and a disregard for cultural contiguity. Achonwa (2015) reflect that:

"Indiscriminate creation of autonomous communities has destroyed the collective sentiments that characterize our rural communities. Communities that once shared a common identity would be quick to go to war against each other in a bid to protect their new identity. We have witnessed today communal clashes, court litigation, assassination, and arson, all in a bid to enjoy autonomy by a community".

Jimoh (2013) while examining "rising deaths from communal clashes in Nigeria" reported that artificial and arbitrary boundaries are responsible for boundary disputes, neglect, and intolerance, among others in Nigeria. Definitely the assets or capital of individuals and groups do come under pressure, dislocations or constrains due to threats.

The outcomes due to livelihood threats in the period covered by this study were insecurity, violence and kidnapping, loss of lives and properties, hunger and food losses, displacement and loss of shelter, a climate of fear and panic; forced migration, diseases, suicidal issues and people being trapped during environmental disaster. Others, especially when government impunity is put into consideration, are identity-based tensions, intolerance, communal clashes, assassinations and flight. Achonwa (2015) shares in this reasoning, that, communities are quick to go to war to protect own identities.

The vulnerable groups more affected were farmers, children, women, youths, aged and disabled persons, students, fishermen and widows. The situation has grave implications on women because of their notable roles in rural livelihood activities and their ubiquity in community activities. The many threats, especially violence, gang operations and herdsmen menace are forcing women-the bastion of rural livelihood, to quit the farms, distant market and meeting places.

The presence of threat factors are associated with the many negative outcomes mentioned. By the same association, they are causative to the vulnerability of groups noticed. All these are supported by the t-test for correlation coefficient run during this study. This is supported by reports from Narayan and Petesch 
(2002) that "Nigeria has been facing poor state functioning, eroding physical, seasonal stresses, crime and conflict".

With the erosion of rural livelihoods through violence, youth gang, government and institutional failure or neglect; ambushing and robbing of farmers and petty traders, a climate of fear has enveloped the rural dwellers.

The chief casualties from the mix of threats factors, the negative outcomes and vulnerabilities are the rural assets and wealth in terms of skills, knowledge and health; inaccessible natural resources; reduced savings and credit; dying formal and informal social relationships; a dislocating transport system, shortage of water supply, lack communication, shelter and household property.

Interventions from environmental and security related agencies were made to stop disaster and their further progression. However, post crises activity and assistance to communities to build capabilities to recover from shocks were missing. In view of the fact that resilience and early recovery after crisis is poor in Nigeria aggravated chaos in the communities continues.

Civil liberty groups are missing in rural livelihood threat mitigation efforts, hence government impunity goes unchallenged; dereliction of duty by intervention agencies is not exposed.

\section{Conclusion and Recommendations}

Threats to livelihoods in Nigeria are expected to become devastating and frequent in the years ahead, due to climate change related problems, growing populations, unguarded settlements, growing culture of violence and hate as well as attacks on migrant quarters and reprisals. Women, the bastion of rural livelihood sustenance, are withdrawing from livelihood activities. Herders are using intimidation and inventing new tricks to maneuver indigenous groups. Unfortunately, threats-mapping is absent. Equally, institutional failures and governmental arbitrariness that prevent diversification and reinforce vulnerability are not being curtailed. Vulnerability in the livelihood threats is even dynamic Women and farmers that suffer during submerging of farmland and cattle-herdsmen violence, while children and the elderly were affected most during flooding of compounds. During communal clashes, youths were affected. Vulnerability is spread out during institutional failure and government arbitrariness. The associated disorder and human insecurity reduces the availability of physical, human, social, natural and financial assets; hence, these researchers recommend as follows:

1) Nigerians should learn to yield to expert advice. It is known that the areas that have been coming under flood have always been noted as risk hazard zones by experts in geo-informatics and meteorologists. People should be discouraged from settling in places that are susceptible to extreme events.

2) The governments should quit their failure fault lines and arbitrary conducts (such as splitting of villages and autonomous communities) that generate collision, flight and tension in the communities.

3) Enabling environment, especially human security, should be created by 
government to enable people return to age long diversified livelihoods. Rural livelihood diversification should target the women, because they are proven masters in this and are the first to become vulnerable.

4) Government agencies and leaders should create resilience and early recovery attitude in rural Nigerians. Flooding and erosion along coastal areas and river banks are inevitable. All it takes is to train and organize people for resilience and send change agents to work out details of early recovery.

5) The romancing of nomadic culture by Nigerian authorities should stop. Wandering for the sake of feeding cattle should be seen as a primitive activity. Let Nigerian authorities create cattle ranches, enforce the arrangement and even establish a value chain for the cattle business from recycling of cattle dung to serve as manure, to milking of cattle, bone crushing factories, wool harvesting, beef storage and processing plants.

6) Leaders should rise above charity to the vulnerable. Emergency management agencies should be strengthened to function, connect and partner with local victims and evaluate programmes with them.

7) Civil society groups should be encouraged in the rural areas in view of their reputation in checking government impunity, arbitrary conducts and excesses.

\section{Conflicts of Interest}

The authors declare no conflicts of interest regarding the publication of this paper.

\section{References}

Achonwa, U. (2015). The Need for Caution on the Creation of Autonomous Communities in Nigeria. Heartland FM News Commentary.

Agbakwuru, J. (2015). Owerri-PH Road Collapses Finally. The Leaders, 9.

Ajani, J. (2012). Rage of Nature: Flood Ravages Communities across Nigeria. Vanguard News.

Ajayi, O. (2012). Oyo State, over 100 Lose Their Lives. Vanguard, 42.

Akinwale, A. A. (2011). Livelihoods and Environmental Challenges in Coastal Communities of Nigeria. Journal of Sustainable Development in Africa, 12, 79-88.

Akinyemi, D. (2012). 300m, One Million Hectres of Rice, Maize Farmlands Gone, 86 Communities Sacked by Flood. Vanguard News.

Alabelewe, A. (2014). Southern Kaduna Killings: Search for Elusive Killings. The Nation, 13.

Amaize, E., \& Omafuame, A. (2012). Lamentation of Flood Victims in Delta. Vanguard, 8.

Amaize, E. (2012). Royal Father Drowns during Evacuation: Villagers Weep. Vanguard News.

Atta, D. (2012). Flood Destroys 400,000 Farmlands, 36,000 Houses in Jigawa. Punch, 7.

Bakare, B. (2015). Fulani Herdsmen and Flood Security. The Nation, 15.

Chambers, R., \& Conway, R. (1992). Sustainable Rural Livelihood: Practical Concepts for 21st Century. Brighton: Institute of Development Studies.

Cord, L. (2002). Rural Poverty. In J. Klugman (Ed.), A Sourcebook for Poverty Reduction 
Strategies (pp. 65-85). Washington DC: The World Bank.

Dani, A. A., \& Moser, C. (2008). Asset-Based Social Policy and Public Action in the Polycentric World. In C. Moser, \& A. A. Dani (Eds.), Assets, Livelihoods, and Social Policy (p. 11). Washington DC: The World Bank.

Daniel, A. (2013). Communal Clashes Tears Nasarawa Apart. Vanguard, 37.

Deininger, K., Narayan, D., \& Sen, B. (2009). Politics of Middle Path: Agrarian Reform and Poverty Dynamics in West Bengal. In D. Narayan (Ed.), Moving out of Poverty: The Promise of Empowerment and Democracy in India USA (pp. 287-347). Washington DC: The World Bank.

Department of Agriculture, Environment and Development Economics, Ohio State University (2015). Adaptation to Climate Changes in Nigeria. http://www.livelihoods.org

DFID (2015). Sustainable Livelihood Frame Work.

Diamond, L. (2005). Empowering the Poor: What Does Democracy Have to Do with It. In D. Narayan (Ed.), Measuring Empowerment: Cross-Disciplinary Perspectives (pp. 403-425). Washington DC: The World Bank. https://doi.org/10.1037/e597202012-019

Diamond, L., \& Morlino, L. (2004). The Quality of Democracy: An Overview. Journal of Democracy, 15, 20-31. https://doi.org/10.1353/jod.2004.0060

Dube, T., \& Phiri, K. (2013). Rural Livelihoods under Stress. The Impact of Climate Change on Livelihoods in South Western Zimbabwe. An American International Journal of Contemporary Research, 3, 11-25.

Duru, P. (2012). We Woke Up inside Water, Victims Comment. Vanguard News.

Ebegbulem, S. (2012). River Nigeria Created 500,000 Refuges, as Dokpesi House Submerges. Vanguard News.

Ejenbi, R. (2015). Communal Clash Claims 45 Lives in Benue. Sunday Sun, 10.

Ellis, F. (1999). Rural Livelihood Diversity in Developing Countries: Evidence and Policy Implications (No. 40). London: Overseas Development Institute.

Ellis, F. (2003). Livelihoods Approach to Migration and Poverty Reduction. Paper Commissioned by the Department for International Development (DFID).

Falola, F., Adetayo, O., Utebo, S., \& Nwogu, S. (2010). Floods: Residents Count Losses as Canoe Operates Rake Money. Punch Metro, 5.

Gasper, D. (2005). Securing Humanity: Situating "Human Security" as Concept and Discourse. Journal of Human Development, 6, 221-245. https://doi.org/10.1080/14649880500120558

Grant, M. J., Button, C. M., \& Snook, B. (2017). An Evaluation of Inter Rater Reliability Measures on Binary Tasks Using d-Prime. Applied Psychological Measurement, 41, 264-276. https://doi.org/10.1177/0146621616684584

Harvard Humanitarian Academy (2013). Year End Report. Advancing the Science and Practice of Humanitarian Response.

Ibirogba, A. (2012). Combating the Threat of Flooding. Guardian, 53.

Ishaka, P. (2015). Addressing the Perennial Herdsmen Famers Conflict. Conflict Will Persist unless There Is a Conscious Effort to Retool Nomadic Farming to Suit the Age and Times. Thisday, 8.

Itua, F. (2013). Outrage over Activities of Fulani Herdsmen. Daily Sun, 17.

Jimoh, A. (2013). Rising from Communal Clashes in Nigeria. Daily Sun, 20.

Morce, S., \& McNamara, N. (2013). Sustainable Livelihood Approach. A Critique and Practice. Berlin: Springer. 
http://www.springer.com/social+sciences/population+studies https://doi.org/10.1007/978-94-007-6268-8

Mosadomi, W. (2012). 117 Communities, 663,000 Persons Affected as Victims Lobby to Make Camp Site Permanent. Vanguard News.

Moser, C., \& Dani, A. A. (2008). Assets, Livelihoods and Social Policy. Washington DC: The World Bank. https://doi.org/10.1596/978-0-8213-6995-1

Narayan, D., \& Petesch, P. (2002). Voices of the Poor from Other Lands. Washington DC: The World Bank.

Narayan, D. (2000). Voices of the Poor. Can Anyone Hear Us? Washington DC: The World Bank. https://doi.org/10.1596/0-1952-1601-6

Obahopo, B. (2012). Frustrated, Two Victims Commit Suicide in Kogi. Vanguard News.

OECD (2014). Guidelines for Resilience Systems Analysis. Paris: OECD Publishing. http://www.oecd.org/publishing/corrigenda

Okoh, G. (2012). Renewed Clash Destroys 40 Houses. This Day, 57.

Okpalaeke, K. (2012). Ohaji, Egbema and Oguta LGA Flood Victims. Announcer, 7.

Okunmadewa, F., Aina, O., Ayoola, G. B., Mamman, A., Nwaeze, N., Odebiyi, T., Shehu, D., \& Zacha, J. (2002). Nigeria, Illbeing and Insecurity. In D. Narayan, \& P. Petesch (Eds.), Voices of the Poor from Other Lands (pp. 98-99). Washington DC: The World Bank.

Onoyume, J. (2012). Rivers State, Flood Disaster Forces Farmers into Premature Harvest. Families Postpone Burial of Loved Ones. Vanguard, 13.

Oyadongha, S. (2012). Even for the Water People of Bayelsa Towns Were Shocked. Vanguard News. https://doi.org/10.18243/eon/2015.8.12.2

Scott, J., \& Marshall, G. (2005). Dictionary of Sociology. New York: Oxford Pub.

Sowale, J. (2015). Cattle Destroy Falae's Farm Again. This Day, 7.

The Leader (2014). Insecurity: Police Escort Embattled Ohaji Women Home. The Leader, 16.

Udo, E. A., Ojinaka, O. C., Raywood, C. N., \& Gift, U. A. (2015). Flood Hazard Analysis and Damage Assessment of 2012 Flood in Anambra State Using GLS and Remote Sensing Approach. American Journal of Geographic Information, 4, 38-51.

Ujamade, V. (2012). Today What We Have Is Sea. Vanguard News.

UN Trust Fund for Human Security (1994). Types of Human Security Threats.

UN Trust Fund for Human Security (2009). Human Security in Theory and Practice.

UNDP (2008). UNDP Policy on Early Recovery. Paris: Bureau for Crisis Prevention and Recovery.

Wrong, D. (1994). The Problem of Order. New York: The Free Press. 
Appendix: Spreadsheet on Threats to Livelihood in Nigeria 2010-2015

\begin{tabular}{|c|c|c|c|c|c|c|}
\hline $\begin{array}{l}\text { Nature } \\
\text { of threat }\end{array}$ & $\begin{array}{c}\text { Places } \\
\text { witnessed }\end{array}$ & $\begin{array}{l}\text { Impacts } \\
\text { of threat }\end{array}$ & $\begin{array}{l}\text { Period } \\
\text { reported }\end{array}$ & $\begin{array}{l}\text { Human } \\
\text { security/social } \\
\text { order }\end{array}$ & $\begin{array}{l}\text { Sources of } \\
\text { information }\end{array}$ & $\begin{array}{c}\text { Most } \\
\text { vulnerable/ } \\
\text { stressed }\end{array}$ \\
\hline \multirow[t]{6}{*}{$\begin{array}{l}\text { Flood and } \\
\text { seasonal } \\
\text { stresses due } \\
\text { to excessive } \\
\text { rains, } \\
\text { overflowing } \\
\text { of rivers and } \\
\text { over- spilling } \\
\text { of dams }\end{array}$} & $\begin{array}{l}\text { Anambra State: } \\
\text { Some specific } \\
\text { communities-Nmiata, } \\
\text { Odekpe, Ossomala, } \\
\text { Osuche,Atani, } \\
\text { Amii,Umuzu, } \\
\text { Akali-Ogidi, } \\
\text { Akali-Ozizor, } \\
\text { Amiyi, Mputu, } \\
\text { Obeagwe, } \\
\text { Ochuche, Ogbakuba, } \\
\text { Ogwu-Aniocha, } \\
\text { Agwuikpele, Obita, } \\
\text { Okpoko, Umunankwo. }\end{array}$ & $\begin{array}{l}\text { Submerging of } \\
\text { farmlands, school } \\
\text { compounds, } \\
\text { police stations, } \\
\text { churches and markets. } \\
\text { Pulling of fences, } \\
\text { hunger and } \\
\text { displacement } \\
\text { of persons }\end{array}$ & $\begin{array}{l}\text { September- } \\
\text { October } \\
2012\end{array}$ & $\begin{array}{c}\text { People } \\
\text { trapped } \\
\text { or cut off, } \\
\text { panic and } \\
\text { flight }\end{array}$ & $\begin{array}{c}\text { Ujamade } \\
(2012)\end{array}$ & $\begin{array}{l}\text { Farmers, } \\
\text { women, } \\
\text { children and } \\
\text { students }\end{array}$ \\
\hline & $\begin{array}{l}\text { Bayelsa State: } \\
\text { Specific } \\
\text { communities- All } \\
\text { except Nembe } \\
\text { and Brass }\end{array}$ & $\begin{array}{l}\text { Destruction of fishing } \\
\text { and farmlands, } \\
\text { submerging of } \\
\text { communities, } \\
\text { diseases due to } \\
\text { defecation in water }\end{array}$ & $\begin{array}{c}\text { October } \\
2012\end{array}$ & $\begin{array}{c}\text { People } \\
\text { trapped } \\
\text { or cut off, } \\
\text { panic and } \\
\text { flight. }\end{array}$ & $\begin{array}{c}\text { Oyadongha } \\
(2012)\end{array}$ & $\begin{array}{l}\text { Fishermen, } \\
\text { Distillers. } \\
\text { Palmwine } \\
\text { tappers. }\end{array}$ \\
\hline & $\begin{array}{c}\text { Benue State: } \\
\text { Specific } \\
\text { communities-Otukpo, } \\
\text { Agatu, Apa, } \\
\text { Kucha, Otebe }\end{array}$ & $\begin{array}{l}\text { Submerging of } \\
\text { business places, } \\
\text { huts and } \\
\text { farmland } \\
\text { displacement }\end{array}$ & $\begin{array}{c}\text { October } \\
2012\end{array}$ & & Duru (2012) & $\begin{array}{l}\text { Students, } \\
\text { women and } \\
\text { children. }\end{array}$ \\
\hline & $\begin{array}{c}\text { Cross River State: } \\
\text { Specific } \\
\text { communities-Obubra, } \\
\text { Abi, Union } \\
\text { Island, Biase. }\end{array}$ & $\begin{array}{l}\text { Submerging of family } \\
\text { houses and compounds, } \\
\text { churches and markets; } \\
\text { drowning of persons. }\end{array}$ & $\begin{array}{c}\text { October } \\
2012\end{array}$ & $\begin{array}{c}\text { Inter } \\
\text { community } \\
\text { movement } \\
\text { and } \\
\text { interaction } \\
\text { affected. }\end{array}$ & $\begin{array}{c}\text { Ujamade } \\
\text { (2012) }\end{array}$ & $\begin{array}{c}\text { Little children, } \\
\text { fishermen, } \\
\text { mothers, }\end{array}$ \\
\hline & $\begin{array}{c}\text { Edo State: } \\
\text { Specific } \\
\text { communities-Yuluwa, } \\
\text { Ofukpo, Agbabu, } \\
\text { Iguzi-Ofukpe, Udaba, } \\
\text { Umudoboh, Anegette, } \\
\text { Unowa, Inyem }\end{array}$ & $\begin{array}{l}\text { Destruction of } \\
\text { buildings, household } \\
\text { properties, food crops, } \\
\text { entire farms, area } \\
\text { councils, human } \\
\text { death, killings of } \\
\text { domestic animals. }\end{array}$ & 2012 & & $\begin{array}{c}\text { Ebegbulem } \\
\quad(2012)\end{array}$ & $\begin{array}{l}\text { Children, } \\
\text { farmers, } \\
\text { aged ones. }\end{array}$ \\
\hline & $\begin{array}{c}\text { Niger State: } \\
\text { Specific } \\
\text { communities- } \\
\text { communities on } \\
\text { downstream Jebba, } \\
\text { Kainji and Shiroro; } \\
\text { plus Chanchanga, } \\
\text { Bosso, Munya, } \\
\text { Borgu, Wushishi, } \\
\text { Mokwa, Bida, } \\
\text { Edari and Lapai. }\end{array}$ & $\begin{array}{l}\text { Human death } \\
\text { and animals, } \\
\text { destruction of } \\
\text { properties and } \\
\text { farm produce, } \\
\text { destruction of } \\
\text { cars, crops } \\
\text { especially cereals. }\end{array}$ & $\begin{array}{c}\text { October } \\
2012\end{array}$ & $\begin{array}{l}\text { Loss of lives, } \\
\text { panic, } \\
\text { displacement } \\
\text { of persons, } \\
\text { inaccessible } \\
\text { homes, } \\
\text { threat to } \\
\text { food security }\end{array}$ & $\begin{array}{l}\text { Mosadomi } \\
\quad(2012)\end{array}$ & $\begin{array}{l}\text { Farmers, } \\
\text { women. }\end{array}$ \\
\hline
\end{tabular}




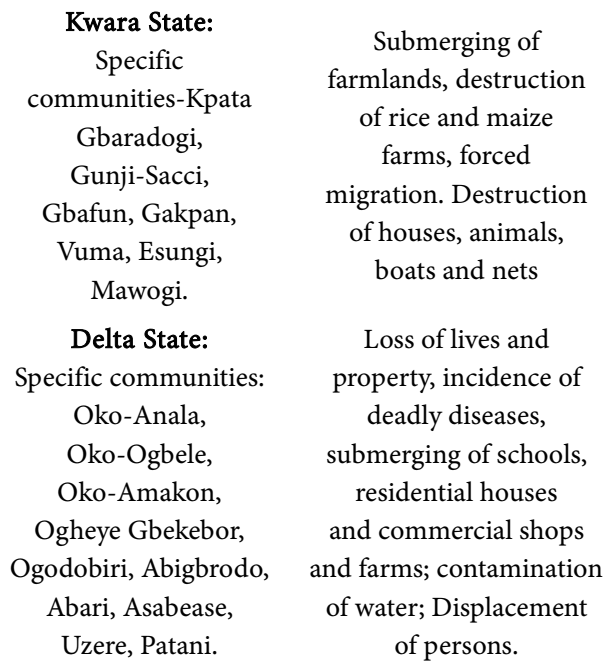

Submerging of

farmlands, destruction

of rice and maize

farms, forced

migration. Destruction

of houses, animals,

boats and nets

Loss of lives and property, incidence of deadly diseases, submerging of schools, residential houses and commercial shops and farms; contamination of water; Displacement of persons.

Rivers State: specific communities-Joinkrama,

Ikodo, Igwechi,

Ongo, Enito, Okobe

\section{Imo State:}

Specific

communities-Egbema, Oguta, Uzoubi Orlu.

\section{Ogun State: \\ Specific}

communities-Warewa

\section{Jigawa State:}

Specific communities

(not mentioned)

but 18 LGAs affected.

Oyo State: Specific communities-Onipepeye, Odo-ona elewe, Odo ona Apata, Nihort, Ijokodo, Sango, Apete, Ajibode, Orogun, Agbowo
Loss of lives

October 2012

Destruction of farms, forced harvests, displacements, postponement of burials,

submerging of houses

Loss of houses, contamination of clean water, submerging of farms and devastation of crops/livestock

Submerging of houses and schools and roads, loss of cattle, destruction of shops.

\section{Destruction of farmlands,} houses, public buildings.

Loss of Lives and properties, mass displacement of persons 2012

October 2012

OctoberNovember 2012

October-

November 2012

October

2012 2012
Displacement of persons,

October panic and migration, threat to food security.

Panic, hunger,

\section{Amaize and}

Omafuame (2012)

Death in

camps, suicide and rumors of suicide, frustrations in the communities, displacements, fear of epidemic, emergence of killer reptiles.

$$
\begin{aligned}
& \text { Fleeing } \\
& \text { for safety }
\end{aligned}
$$

Panic, bitter

September

Homelessness, fleeing to other communities

Atta (2012) lola, Adetayo, Utebo and Nwogu (2010) threat threat

Fear, death,

October 2012 severed communities
Farmers and disabled persons
Widows, Orphaned children. 


\section{Continued}

\begin{tabular}{|c|c|c|c|c|c|c|}
\hline $\begin{array}{c}\text { Herdsmen } \\
\text { Activity }\end{array}$ & $\begin{array}{l}\text { Jigawa, Nasarawa, } \\
\text { Benue, Ondo, } \\
\text { Imo, Ebonyi, } \\
\text { Kaduna(southern), } \\
\text { Cross River, FCT, } \\
\text { Delta, Plateau, } \\
\text { Edo and many } \\
\text { un-named states }\end{array}$ & $\begin{array}{l}\text { Encroachment } \\
\text { into farms, } \\
\text { destruction of } \\
\text { food crops and } \\
\text { cereal fields, } \\
\text { trespass on } \\
\text { peoples homesteads }\end{array}$ & 2015 & $\begin{array}{l}\text { Food insecurity, } \\
\text { killings, } \\
\text { threat to life, } \\
\text { violence and } \\
\text { feuds, } \\
\text { kidnapping, } \\
\text { violation of } \\
\text { rights of } \\
\text { indigenous } \\
\text { people, } \\
\text { blocking of } \\
\text { highways by } \\
\text { animals, } \\
\text { terrorism, } \\
\text { raping. }\end{array}$ & $\begin{array}{l}\text { Bakare (2015) } \\
\text { Sowale (2015) } \\
\text { Itua (2013) } \\
\text { Alabelewe (2014) }\end{array}$ & $\begin{array}{l}\text { Farmers, } \\
\text { women, youths, } \\
\text { community } \\
\text { leaders. }\end{array}$ \\
\hline $\begin{array}{c}\text { Government } \\
\text { neglect } \\
\text { Government } \\
\text { arbitrariness }\end{array}$ & $\begin{array}{l}\text { Owerri-Portharcourt } \\
\text { road. } \\
\text { Most states of Nigeria }\end{array}$ & $\begin{array}{l}\text { Cut off of Ohaji, } \\
\text { Umuapu food basket } \\
\text { areas of Imo State, } \\
\text { damage to vehicles } \\
\text { Creation of artificial } \\
\text { boundaries, violent } \\
\text { communal clashes, } \\
\text { impositions, } \\
\text { assassinations, flight, } \\
\text { violent splitting of } \\
\text { communities, } \\
\text { destruction of } \\
\text { collective sentiments }\end{array}$ & $\begin{array}{l}2013-2015 \\
2005-2015\end{array}$ & $\begin{array}{l}\text { Pains and } \\
\text { anguish, } \\
\text { provocation } \\
\text { of the Youths } \\
\text { Physical } \\
\text { attacks, } \\
\text { assassinations } \\
\text { and intolerance }\end{array}$ & $\begin{array}{c}\text { The Leader } \\
\text { Newspaper } \\
\text { September (2015) } \\
\text { Jimoh (2013) } \\
\text { Achonwa (2015) }\end{array}$ & All citizens \\
\hline \multirow[t]{3}{*}{$\begin{array}{c}\text { Communal } \\
\text { Violence and } \\
\text { Gang activities }\end{array}$} & $\begin{array}{c}\text { Benue State: } \\
\text { Mbayangeh and } \\
\text { Mbashine } \\
\text { communities, } \\
\text { Ologba and Egba } \\
\text { communities. } \\
\text { Nasarawa State } \\
\text { Assakio, Agyaragu }\end{array}$ & $\begin{array}{l}\text { Destruction of } \\
\text { economic trees } \\
\text { and palm produce, } \\
\text { destruction of } \\
\text { fish ponds. } \\
\text { Destruction of } \\
\text { lives and property, } \\
\text { forfeiture of farmlands. }\end{array}$ & $\begin{array}{l}\text { July } 2012 \\
\text { June, } \\
\text { November } \\
2012\end{array}$ & $\begin{array}{l}\text { Shelter and } \\
\text { food } \\
\text { threatened. } \\
\text { Attacks and } \\
\text { counter attacks } \\
\text { by rival groups, } \\
\text { killings, deadly } \\
\text { clashes of rival } \\
\text { groups, seizure } \\
\text { of farmlands. }\end{array}$ & $\begin{array}{l}\text { Okoh (2012) } \\
\text { Ejenbi (2015) } \\
\text { Daniel (2013) }\end{array}$ & $\begin{array}{l}\text { Youths and } \\
\text { community } \\
\text { leaders. }\end{array}$ \\
\hline & Southern Kaduna & $\begin{array}{l}\text { Destruction of } \\
\text { lives and } \\
\text { property, Farms }\end{array}$ & $\begin{array}{c}\text { Frequent } \\
\text { occurrence }\end{array}$ & $\begin{array}{l}\text { Armed } \\
\text { invasion, } \\
\text { terrorism, } \\
\text { killings }\end{array}$ & Alabelewe (2014) & $\begin{array}{l}\text { Women, } \\
\text { community } \\
\text { leaders. }\end{array}$ \\
\hline & $\begin{array}{l}\text { Imo State: Mainly } \\
\text { Mgbuishi Ohaji } \\
\text { community }\end{array}$ & $\begin{array}{l}\text { Abandonment of } \\
\text { farms and homes }\end{array}$ & 2014 & $\begin{array}{l}\text { Fear, physical } \\
\text { attacks, riots }\end{array}$ & $\begin{array}{l}\text { The Leader } \\
\text { Newspaper } \\
\text { August } 2014\end{array}$ & $\begin{array}{l}\text { Women, } \\
\text { Farmers. }\end{array}$ \\
\hline $\begin{array}{c}\text { Communal } \\
\text { Violence and } \\
\text { Gang Activities }\end{array}$ & $\begin{array}{l}\text { Most States } \\
\text { in Nigeria }\end{array}$ & $\begin{array}{l}\text { Socio-economic, } \\
\text { physical and } \\
\text { emotional } \\
\text { imbalances } \\
\text { among the people. } \\
\text { Class struggle } \\
\text { of all sorts. }\end{array}$ & $2012-2015$ & $\begin{array}{l}\text { Upsurge of } \\
\text { killings, } \\
\text { clashes, } \\
\text { acquisition } \\
\text { of arms, rape. }\end{array}$ & Jimoh (2013) & Youths. \\
\hline
\end{tabular}

Source: Data compiled and transformed by Onyekwere and Nworgu 2015. 